\title{
Highly oxidized Pt species stabilized inside carbon nanotubes for asymmetric hydrogenation
}

\author{
Zaihong Guan, Shengmei Lu, Can Li* \\ State Key Laboratory of Catalysis, Dalian Institute of Chemical Physics, Chinese Academy of Sciences, Dalian 116023, Liaoning, China
}

\section{A R T I C L E I N F O}

Article history:

Received 20 January 2015

Accepted 3 March 2015

Published 20 September 2015

\section{Keywords:}

Carbon nanotube

$\alpha$-Ketoester

Asymmetric hydrogenation

Platinum nanoparticle

Oxidized state

\begin{abstract}
A B S T R A C T
The chemical state and its influence on Pt species in or outside of the channels of CNTs and the effect on the asymmetric hydrogenation of $\alpha$-ketoester were investigated. XPS analysis showed that $13 \% \mathrm{Pt}$ species in a highly oxidized state $\left(\mathrm{Pt}^{4+}\right)$ were stabilized inside the channels in the presence of $\mathrm{Na}^{+}$. There were more highly oxidized Pt species inside the CNTs than outside. The highly oxidized Pt species promoted the interaction between the nanoparticle and chiral modifier, which is crucial for high enantioselectivity. Hydrogen temperature programmed desorption showed that $\mathrm{Pt}$ nanoparticles confined in the channels can better activate hydrogen, which contributed to their high activity even at low hydrogen pressure.
\end{abstract}

(C) 2015, Dalian Institute of Chemical Physics, Chinese Academy of Sciences. Published by Elsevier B.V. All rights reserved.

\section{Introduction}

Due to the space confining effect provided by the well-defined one dimensional channel of carbon nanotubes (CNTs), catalysis inside CNTs has received attention. Several types of catalytic reactions in CNTs have been reported, including liquid phase hydrogenation reactions [1-3] and gas phase reactions [4-9]. In most cases, the activity and/or selectivity were enhanced when the catalytic reaction was confined in the channels of the CNTs. However, the origin of the enhanced catalytic performance still remains unknown for most cases. Only a few reports have focused on understanding the enhanced performance and the explanations were limited to a few reactions [10-13]. In order to understand the origin of the enhanced performance inside CNTs and the nano-space confinement effect, it is imperative to comprehensively investigate the factors that influence the reaction inside the CNTs.

Asymmetric hydrogenation of $\alpha$-ketoester on cinchonidine
(CD) modified Pt catalysts has been regarded as one of the milestones in heterogeneous asymmetric catalysis. New findings and applications can still be seen in recent years [14-16]. CNTs have been used as the support to load metals for asymmetric hydrogenation $[17,18]$. But the initial research did not focus on introducing metal nanoparticles into the channels of the CNTs. Our previous study demonstrated heterogeneous asymmetric catalysis confined within the CNTs [19] (Scheme 1). It was found that the catalytic performance of Pt nanoparticles encapsulated in the channels (denoted as Pt/CNTs(in)) in the asymmetric hydrogenation of $\alpha$-ketoesters was much better than that of Pt nanoparticles outside the channels (denoted as Pt/CNTs(out)) [14] (Fig. 1). A trace amount of water in the solvent was found to further promote the performance of $\mathrm{Pt} / \mathrm{CNTs}$ (in). For the reaction in an anhydrous solvent, Pt/CNTs(in) was still superior to Pt/CNTs(out) [20]. Using another widely studied asymmetric hydrogenation of $\alpha, \beta$-unsaturated acid on CD modified Pd catalysts [21-23], we

\footnotetext{
* Corresponding author. Tel: +86-411-84379070; Fax: +86-411-84694447; E-mail: canli@dicp.ac.cn This work was supported by the National Natural Science Foundation of China $(20921092,21227801)$. 


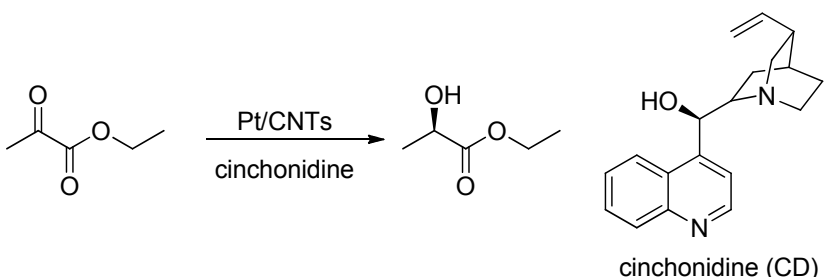

Scheme 1. Asymmetric hydrogenation of ethyl pyruvate (EtPy).
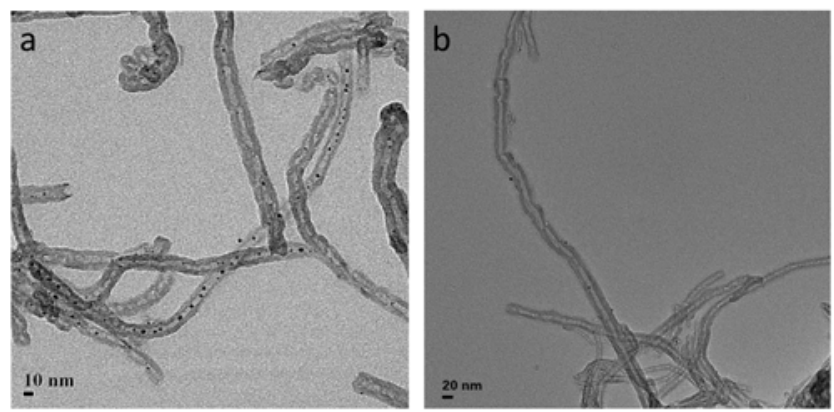

Fig. 1. TEM images of (a) Pt nanocatalyst confined inside the CNT nanochannels (Pt/CNTs(in)) and (b) Pt nanocatalyst loaded onto the outer surface of the CNTs (Pt/CNTs(out)).

also found that Pd nanoparticles inside CNTs delivered better performance than Pd nanoparticles outside the channels [24]. However, the main factors giving this significant difference are still not known. We previously suggested that the difference in catalytic performance is partly related to the enrichment of the chiral modifier CD and reactant in the channels [19,20,24]. Besides the enrichment effect, other possible factors such as the Pt nanoparticles and hydrogen pressure may also contribute to the enhanced performance of confined Pt nanoparticles. In this paper, we show that Pt species in a highly oxidized state can be stabilized inside the channels of CNTs in the presence of $\mathrm{Na}^{+}$, and that this benefits the interaction between the nanoparticles and chiral modifier, resulting in high enantioselectivity. Pt nanoparticles confined in the channels also had a stronger hydrogen adsorption, which may be further responsible for the high activity.

\section{Experimental}

\subsection{Catalyst preparation}

The loading of Pt for all the catalysts were $5 \mathrm{wt}$ \% (weight percent). Pt/CNTs(in) and Pt/CNTs(out) were prepared according to our previous report [19]. The pristine CNTs were first oxidized by $\mathrm{HNO}_{3}\left(68\right.$ wt.\%) at $140{ }^{\circ} \mathrm{C}$ for $12 \mathrm{~h}$, and then filtered and washed with deionized water, then dried at $60{ }^{\circ} \mathrm{C}$ for $18 \mathrm{~h}$.

Pt/CNTs(in) was prepared as follows. The oxidized CNTs (1.0 g) were immersed in an aqueous solution of $\mathrm{H}_{2} \mathrm{PtCl}_{6}$ (25 $\mathrm{mL}, 10.25 \mathrm{mmol} / \mathrm{L}$ ) followed by an ultrasonic treatment for $3 \mathrm{~h}$. Then the mixture was stirred for $48 \mathrm{~h}$ at room temperature, slowly heated to $110{ }^{\circ} \mathrm{C}$ at the rate of $1{ }^{\circ} \mathrm{C} / \mathrm{min}$ and held at 110 ${ }^{\circ} \mathrm{C}$ for $24 \mathrm{~h}$. The slow drying method was beneficial to introducing the $\mathrm{Pt}$ precursor into the channels. The dried mixture was reduced in a sodium formate solution $(42 \mathrm{mg} / \mathrm{mL})$ at $90{ }^{\circ} \mathrm{C}$ for $1 \mathrm{~h}$, filtrated, washed with deionized water and dried at $80^{\circ} \mathrm{C}$ for $18 \mathrm{~h}$.

For the preparation of Pt/CNTs(out), the oxidized CNTs (1.0 g) were immersed in xylene $(25 \mathrm{~mL})$ followed by an ultrasonic treatment for $3 \mathrm{~h}$ at room temperature. After the addition of $\mathrm{H}_{2} \mathrm{PtCl}_{6}$ solution $(2.72 \mathrm{~mL}, 94.21 \mathrm{mmol} / \mathrm{L})$, the mixture was stirred for $0.5 \mathrm{~h}$. Then the mixture was also reduced with sodium formate solution as described in the preparation of Pt/CNTs(in), filtered, and dispersed in ethanol $(50 \mathrm{~mL})$ for extraction of the residual xylene for 5 times. Finally the mixture was filtered and washed with deionized water and dried at 80 ${ }^{\circ} \mathrm{C}$ for $18 \mathrm{~h}$.

Two reference catalysts were also prepared. After the introduction of the $\mathrm{Pt}$ precursor into the channels and the drying procedure, the catalyst was pre-reduced in a hydrogen stream at $90{ }^{\circ} \mathrm{C}$ for $1 \mathrm{~h}$ instead of in sodium formate solution (denoted as Pt/CNTs(in- $\mathrm{H}_{2}$ )). The $\mathrm{Pt}$ nanoparticles of $\mathrm{Pt} / \mathrm{CNTs}\left(\mathrm{in}-\mathrm{H}_{2}\right.$ ) were well dispersed in the channels of CNTs. The catalyst with Pt nanoparticles randomly dispersed inside and outside the channels of CNTs was prepared (denoted as $\mathrm{Pt} / \mathrm{CNTs}\left(\mathrm{H}_{2}\right)$ ). The oxidized CNTs (1.0 g) were immersed in an aqueous solution of $\mathrm{H}_{2} \mathrm{PtCl}_{6}(25 \mathrm{~mL}, 10.25 \mathrm{mmol} / \mathrm{L}$ ) and stirred

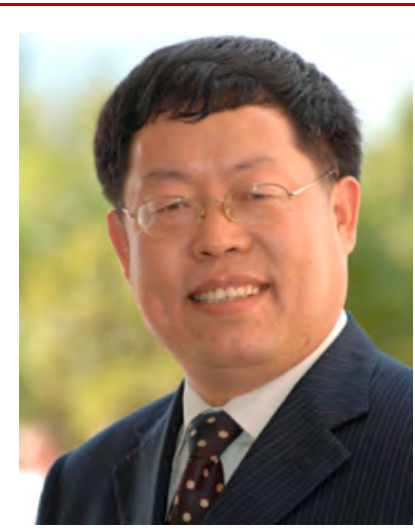

Can Li (Dalian Institute of Chemical Physics, Chinese Academy of Science) received the Catalysis Achievement Award (the Dayu Zhang Award) in 2014, which was presented by The Catalysis Society of China. Professor Can Li received his Ph.D. degree in Physical Chemistry from Dalian Institute of Chemical Physics, Chinese Academy of Sciences, in 1989, and he joined the same institute and was promoted to full professor in 1993. He did postdoctoral research on catalysis and UV Raman spectroscopy at Northwestern University and was visiting professor at Lehigh University, the University of Liverpool, and The Queensland University, and he was awarded the JSPS Professor at Waseda University, Tokyo University of Technology, and Hokkaido University. He was an invited professor at Université Pierre et Marie Curie, Paris VI. He was the President of the International Association of Catalysis Societies (2008-2012). Currently, he is the director of the State Key Laboratory of Catalysis, and the director of the Dalian National Laboratory for Clean Energy (DNL). His research interests include (1) UV Raman spectroscopy and ultrafast spectroscopy; (2) environmental catalysis and green catalysis; (3) heterogeneous asymmetric catalysis; and (4) solar energy utilization based on photocatalysis, photoelectrocatalysis and photovoltaic cells. He has published more than 500 peer-reviewed papers with over 10000 citations. 
for $6 \mathrm{~h}$ at room temperature. The mixture was heated to $110^{\circ} \mathrm{C}$ at the rate of $5{ }^{\circ} \mathrm{C} / \mathrm{min}$ and held at $110{ }^{\circ} \mathrm{C}$ for $24 \mathrm{~h}$. The dried sample was reduced in $\mathrm{H}_{2}$ stream at $90^{\circ} \mathrm{C}$ for $1 \mathrm{~h}$ instead.

All the catalysts described above were stored in air.

\subsection{Catalyst test}

General procedure for hydrogenation: Take Pt/CNTs(in) as an example. $10 \mathrm{mg}$ of Pt/CNTs(in) was pretreated for a set time in a $\mathrm{H}_{2}$ stream at a set temperature. Under standard conditions, the reaction was carried out using $10 \mathrm{mg}$ pretreated catalysts, 2 $\mathrm{mL}$ solvent and $2 \mathrm{mg}$ cinchonidine in a $100 \mathrm{~mL}$ of stainless-steel autoclave. The substrate $(0.1 \mathrm{~mL})$ was added after magnetically stirring the mixture under $\mathrm{H}_{2}$ for 2 min. Then the autoclave was purged with $\mathrm{H}_{2}$ for 4 times to eliminate residual air, followed by setting the final $\mathrm{H}_{2}$ pressure to 4-6 MPa. The reaction was carried out by magnetically stirring for a set time at room temperature. Then the catalyst was centrifuged, and the supernatant organic layer was diluted with ethanol. For EtPy, the conversion and enantiomeric excess were determined on a gas chromatograph (Agilent 6890) equipped with HP 19091G-B213 capillary column $(30 \mathrm{~m} \times 0.32 \mu \mathrm{m} \times 0.25 \mu \mathrm{m})$.

The activity of the hydrogenation was expressed as the average turnover frequency (TOF). TOF $=\left(\left[\mathrm{M}_{0}\right] \times\right.$ conversion $) /\left(\left[\mathrm{M}_{\mathrm{Pt}}\right] \times D_{\mathrm{Pt}} \times(\right.$ reaction time $\left.)\right) .\left[\mathrm{M}_{0}\right]$ is the initial molar concentration of the reactant. [MPt] is the $\mathrm{Pt}$ molar concentration used in the reaction. $D \mathrm{Pt}$ is the metal dispersion of Pt obtained by CO chemisorption. The ee (\%) of the $R$ isomer was expressed as ee $(\%)=([R]-[S]) \times 100 /([S]+[R])$.

\subsection{Catalyst characterization}

TEM images were obtained on a TECNAI G ${ }^{2}$ electron microscope with an accelerating voltage of $100 \mathrm{kV}$. For the TEM measurement, the powder sample was dispersed in ethanol and dripped onto a copper grid covered with a carbon film and then dried in air. $\mathrm{N}_{2}$ adsorption was performed on a Micromeritics ASAP 2020 volumetric adsorption analyzer after the sample was outgassed at $120^{\circ} \mathrm{C}$ for $6 \mathrm{~h}$. $\mathrm{H}_{2}$-TPD was carried out on a Micromeritics AutoChem 2910 analyzer after the sample was outgassed at $120^{\circ} \mathrm{C}$ for $6 \mathrm{~h}$ before $\mathrm{H}_{2}$ adsorption. After the adsorption reached equilibrium, the sample was heated at the rate of $10{ }^{\circ} \mathrm{C} / \mathrm{min}$ to $900{ }^{\circ} \mathrm{C}$. CO chemisorption was performed on a Quantachrome AUTOSORB-1-MS volumetric adsorption analyzer after the sample was outgassed at $120{ }^{\circ} \mathrm{C}$ for $6 \mathrm{~h}$. X-ray photoelectron spectroscopic analysis of the catalysts was performed on a VG ESCAB mk-2 instrument using $\mathrm{Al} K_{\alpha}$ $(1486.6 \mathrm{eV}, 12.5 \mathrm{kV}, 250 \mathrm{~W})$ radiation. The sample was pressed into a sample holder and evacuated to $0.4-0.8 \times 10^{-6} \mathrm{~Pa}$ for 12 $h$. Then the sample was in situ reduced in $\mathrm{H}_{2}$ at a set temperature before the measurement.

Adsorption of CD and EtPy on the catalyst was carried out as follows. The catalyst was first pretreated in a $\mathrm{H}_{2}$ stream at 225 ${ }^{\circ} \mathrm{C}$ for $2 \mathrm{~h}$ before the adsorption. The working solution of $\mathrm{CD}$ was made by dissolving $5 \mathrm{mg} C D$ in $100 \mathrm{~mL}$ of acetic acid. The mixture of catalyst (20 mg) and the working solution of CD (4 $\mathrm{mL}$ ) was stirred at room temperature for a set time, followed by centrifuging. $2 \mathrm{~mL}$ of the supernatant was extracted and analyzed on a SHIMADZU UV-2550 UV/Vis spectrophotometer using acetic acid solution for reference. For the adsorption of EtPy, the working solution was made by dissolving $1.342 \mathrm{mmol}$ of EtPy in $100 \mathrm{~mL}$ of acetic acid. $20 \mathrm{mg}$ of catalyst was dispersed in $4 \mathrm{~mL}$ work solution and stirred for a set time. Then $2 \mathrm{~mL}$ of supernatant was taken out and analyzed by GC. The adsorption molar ratio of CD or EtPy was defined as Adsorption molar ratio $=1-($ Concentration in supernatant $) /($ Original concentration in working solution).

\section{Results and discussion}

\subsection{Chemical state of the platinum species}

Using X-ray photoelectron spectroscopy (XPS), we analyzed the composition of carbon and Pt species in Pt/CNTs(in) and $\mathrm{Pt} / \mathrm{CNTs}$ (out). No obvious difference in the distribution of carbon species of Pt/CNTs(in) and Pt/CNTs(out), and little difference after the reduction treatment was found.

The deconvolution of the Pt $4 \mathrm{f}$ region illustrated that there were three Pt species in the Pt/CNTs. The doublet with the binding energy of 71.0 ( $\left.\mathrm{Pt} 4 f_{7 / 2}\right)$ and $74.45 \mathrm{eV}\left(\mathrm{Pt} 4 f_{5 / 2}\right)$ can be attributed to metallic $\mathrm{Pt}\left(\mathrm{Pt}^{0}\right)$, the doublet at $74.0 \mathrm{eV}\left(\mathrm{Pt} 4 f_{7 / 2}\right)$ and $77.45 \mathrm{eV}\left(\mathrm{Pt} 4 f_{5 / 2}\right)$ to $\mathrm{PtO}\left(\mathrm{Pt}^{2+}\right)$ species and the doublet at $75.0 \mathrm{eV}\left(\mathrm{Pt} 4 f_{7 / 2}\right)$ and $78.45 \mathrm{eV}\left(\mathrm{Pt} 4 f_{5 / 2}\right)$ to $\mathrm{PtO}_{2}\left(\mathrm{Pt}^{4+}\right)$ species [25]. With increasing reduction, higher reduction temperature and longer reduction time, the amount of unreduced oxidized $\mathrm{Pt}$ species decreased while that of $\mathrm{Pt}^{0}$ increased (Table 1, entries 1-4).

The catalytic activity of the Pt/CNTs catalysts was tested with the hydrogenation of EtPy. The results are listed in Table 1. For the hydrogenation of $\alpha$-ketoester, $\mathrm{Pt}^{0}$ is the active site for the activation of hydrogen, adsorption of the chiral modifier, and hydrogenation of $\alpha$-ketoester [26,27]. The reference experiments indicated that the asymmetric hydrogenation of $\alpha$-ketoester did not proceed without the $\mathrm{Pt}^{0}$ species (Table 2 ). So the $\mathrm{Pt}^{0}$ species is the primary active site in the reaction. However, when the amounts of $\mathrm{Pt}^{0}$ in Pt/CNTs(in) and $\mathrm{Pt} / \mathrm{CNTs}$ (out) were further increased by a higher reduction temperature, the enantioselectivity was decreased (Table 1,

Table 1

XPS spectra data and activity of Pt catalysts in the asymmetric hydrogenation of EtPy.

\begin{tabular}{lccccccc}
\hline Entry & Catalyst & Method & $\mathrm{Pt}^{0}$ & $\mathrm{Pt}^{2+}$ & $\mathrm{Pt}^{4+}$ & $\begin{array}{c}\mathrm{TOF} \\
\left(10^{4} \mathrm{~h}^{-1}\right)\end{array}$ & $\begin{array}{c}\text { ee } \\
(\%)\end{array}$ \\
\hline 1 & $\mathrm{Pt} / \mathrm{CNTs}(\mathrm{in})$ & $\mathrm{A}$ & 63.7 & 22.9 & 13.4 & 9.6 & 95 \\
2 & $\mathrm{Pt} / \mathrm{CNTs}(\mathrm{in})$ & $\mathrm{B}$ & 79.5 & 13.4 & 7.1 & 7.7 & 90 \\
3 & $\mathrm{Pt} / \mathrm{CNTs}(\mathrm{out})$ & $\mathrm{A}$ & 67.3 & 32.7 & 0 & 1.6 & 74 \\
4 & $\mathrm{Pt} / \mathrm{CNTs}(\mathrm{out})$ & $\mathrm{B}$ & 79.6 & 20.4 & 0 & 0.2 & 62 \\
5 & $\mathrm{Pt} / \mathrm{AC}$ & $\mathrm{A}$ & 60.3 & 39.7 & 0 & 0.7 & 61 \\
6 & $\mathrm{Pt} / \mathrm{Al}_{2} \mathrm{O}_{3}$ & $\mathrm{~A}$ & 81.7 & 5.0 & 13.3 & 1.0 & 90 \\
\hline \multicolumn{2}{l}{ Conditions: $10 \mathrm{mg}$ of $\mathrm{Pt} / \mathrm{CNTs}, 2.0 \mathrm{mg}$ cinchonidine $(6.725 \mu \mathrm{mol}), 0.2$}
\end{tabular}

Conditions: $10 \mathrm{mg}$ of Pt/CNTs, $2.0 \mathrm{mg}$ cinchonidine (6.725 $\mu \mathrm{mol}$ ), 0.2 $\mathrm{mL}$ of substrate, $2 \mathrm{~mL}$ acetic acid (containing 0.96 wt.\% water), $\mathrm{H}_{2}$ pressure of $6.5 \mathrm{MPa}, 20^{\circ} \mathrm{C}$. Reaction time: $1 \mathrm{~min}$ for Pt/CNTs(in) and 3 min for the others.

A $-\mathrm{H}_{2}$ reduction at $225^{\circ} \mathrm{C}$ for $2 \mathrm{~h}$ before test.

$\mathrm{B}-\mathrm{H}_{2}$ reduction at $400^{\circ} \mathrm{C}$ for $2 \mathrm{~h}$ before test. 
Table 2

Catalytic activity of Pt/CNTs and Pt precursor species in the asymmetric hydrogenation of EtPy.

\begin{tabular}{lccc}
\hline Entry & Catalyst & Conversion (\%) & ee (\%) \\
\hline 1 & $\mathrm{~K}_{2} \mathrm{PtCl}_{4}{ }^{\mathrm{a}}$ & 0 & 0 \\
2 & $\mathrm{H}_{2} \mathrm{PtCl}_{6}{ }^{\mathrm{a}}$ & 0 & 0 \\
3 & $\mathrm{PtO}_{2}{ }^{\mathrm{a}}$ & 0 & 0 \\
4 & $\mathrm{Pt} / \mathrm{CNTs}(\mathrm{in})^{\mathrm{a}}$ & $>95$ & 95 \\
5 & $\mathrm{Pt} / \mathrm{CNTs}(\mathrm{out})^{\mathrm{a}}$ & $>95$ & 75 \\
6 & $\mathrm{Pt} / \mathrm{CNTs}\left(\mathrm{in}-\mathrm{H}_{2}\right)^{\mathrm{b}}$ & 56 & 60 \\
\hline
\end{tabular}

Conditions: $0.5 \mathrm{mg} \mathrm{Pt}, 2.0 \mathrm{mg}$ cinchonidine $(6.725 \mu \mathrm{mol}), 0.2 \mathrm{~mL}$ of substrate, $2 \mathrm{~mL}$ acetic acid, $\mathrm{H}_{2}$ pressure of $6.5 \mathrm{MPa}, 25^{\circ} \mathrm{C}$.

Reaction time: a $10 \mathrm{~min}$; $\mathrm{b} 1 \mathrm{~min}$.

entries 1-4). Thus, we considered that for Pt/CNTs(in) and $\mathrm{Pt} / \mathrm{CNTs}$ (out), besides $\mathrm{Pt}^{0}$ as the primary active site, another component of the Pt nanoparticles, possibly some unreduced oxidized Pt species played a role in the reactions.

As listed in Table 1, the major difference between Pt/CNTs(in) and Pt/CNTs(out) was the composition of the oxidized Pt species. For Pt/CNTs(out), no highly oxidized Pt species $\left(\mathrm{Pt}^{4+}\right)$ were detected when it was reduced at $225^{\circ} \mathrm{C}$ for $2 \mathrm{~h}$ (Method A, Table 1, entry 3). As for Pt/CNTs(in), the $\mathrm{Pt}^{4+}$ species still remained at $13 \%$ (Table 1 , entry 1). It is noteworthy that the $\mathrm{Pt}^{4+}$ species in $\mathrm{Pt} / \mathrm{CNTs}$ (in) even remained at $7 \%$ after it was reduced at $400{ }^{\circ} \mathrm{C}$ for $2 \mathrm{~h}$ (Method B, Table 1, entry 2). Two representative commercial $\mathrm{Pt}$ catalysts, $\mathrm{Pt} / \mathrm{AC}$ and $\mathrm{Pt} / \mathrm{Al}_{2} \mathrm{O}_{3}$ were also investigated (Table 1 , entries 5,6 ). The XPS results showed that no $\mathrm{Pt}^{4+}$ species existed in commercial $\mathrm{Pt} / \mathrm{AC}$ after reduction in a $\mathrm{H}_{2}$ stream at $225^{\circ} \mathrm{C}$ for $2 \mathrm{~h}$ (Method A) and only moderate enantioselectivity (61\% ee) was obtained (Table 1, entry 5). For the commercial $\mathrm{Pt} / \mathrm{Al}_{2} \mathrm{O}_{3}, 13 \%$ $\mathrm{Pt}^{4+}$ species remained after reduction in a $\mathrm{H}_{2}$ stream at $225{ }^{\circ} \mathrm{C}$ for $2 \mathrm{~h}$ (Method A, Table 1, entry 6) and 90\% enantioselectivity was achieved (Table 1, entry 6). The binding energy of $\mathrm{Al} 2 \mathrm{p}$ in $\mathrm{Al}_{2} \mathrm{O}_{3}$ is centered at $74.7 \mathrm{eV}$, which was enveloped by the Pt $4 \mathrm{f}$ region from 71-77 eV [28], making it difficult to accurately analyze the composition of the Pt species. Only a few studies on the XPS analysis of $\mathrm{Pt}$ species in $\mathrm{Pt} / \mathrm{Al}_{2} \mathrm{O}_{3}$ have been reported [29-32]. However, the promotion effect of oxidized Pt species in $\mathrm{Pt} / \mathrm{Al}_{2} \mathrm{O}_{3}$ on a reaction such as propane oxidation was observed [32]. So the important role of the oxidized Pt species, especially the highly oxidized $\mathrm{Pt}$ species $\left(\mathrm{Pt}^{4+}\right)$, in the asymmetric hydrogenation of $\alpha$-ketoester may have been missed in the previous study. The XPS analysis showed that more highly oxidized Pt species can be stabilized within the channels of the CNTs.

To understand the role of the oxidized Pt species, the mechanism of this reaction has to be considered. The reaction mechanism of the asymmetric hydrogenation of $\alpha$-ketoester has been extensively studied since its discovery by Orito et al. $[33,34]$. There is much discussion of this in several recent reviews [35-38]. The widely accepted conclusions about the mechanism can be summarized as follows. Hydrogen is dissociatively adsorbed on the Pt surface. In the situation that most favor the enantioselectivity, the cinchona modifier is anchored on the Pt surface through its quinoline ring using the SO3 con- figuration. The quinuclidine $\mathrm{N}$ of the cinchona modifier is protonated by either the dissociated $\mathrm{H}$ or the proton from the protic solvent, such as acetic acid, and it then interacts with the $\alpha$-ketoester through the $\mathrm{N}-\mathrm{H}-\mathrm{O}$ bond, which was confirmed by theoretical calculations [39] and in situ IR spectroscopy results[27,40]. Based on our results, we propose that the role of the oxidized Pt species is also important in the reaction. As shown in Fig. 2, the existence of the oxidized Pt species, especially the highly oxidized Pt species, increase the electrophilicity of Pt nanoparticles, which enhances the interaction between the $\mathrm{CD} /$ reactant and Pt nanoparticles. This results in a better chiral environment on the surface of the Pt nanoparticles for high enantioselectivity.

Figure 3 shows the adsorption of CD by Pt/CNTs(in), Pt/CNTs(out) and oxidized CNTs (denoted as ox-CNTs, used as the support). The adsorption fraction on Pt/CNTs(in) reached 90\%, which is higher than that on Pt/CNTs(out) and ox-CNTs. We suggest that this high $\mathrm{CD}$ adsorption fraction on Pt/CNTs(in) was due to there being more electrophilic Pt nanoparticles confined in the channels. For Pt/CNTs(out), the Pt nanoparticles were less electrophilic, which led to almost the same CD adsorption fraction as ox-CNTs.

For the reactant EtPy, the adsorption fraction on Pt/CNTs(in) was also higher than that on Pt/CNTs(out) or ox-CNTs (Fig. 4). The more electrophilic Pt nanoparticles in the channels "entrap" more EtPy through the interaction with the

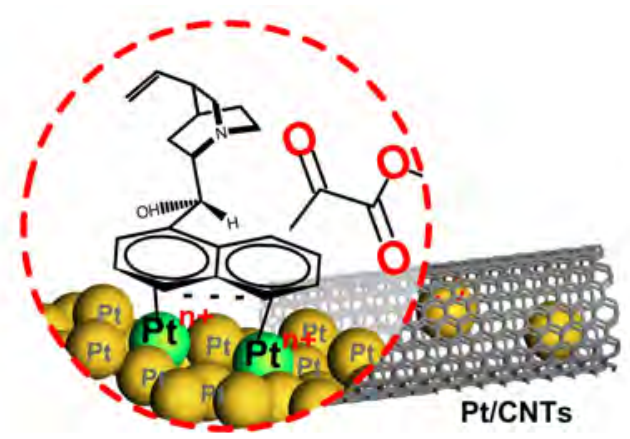

Fig. 2. Role of oxidized Pt species in CD and EtPy adsorption on Pt nanoparticles inside CNTs.

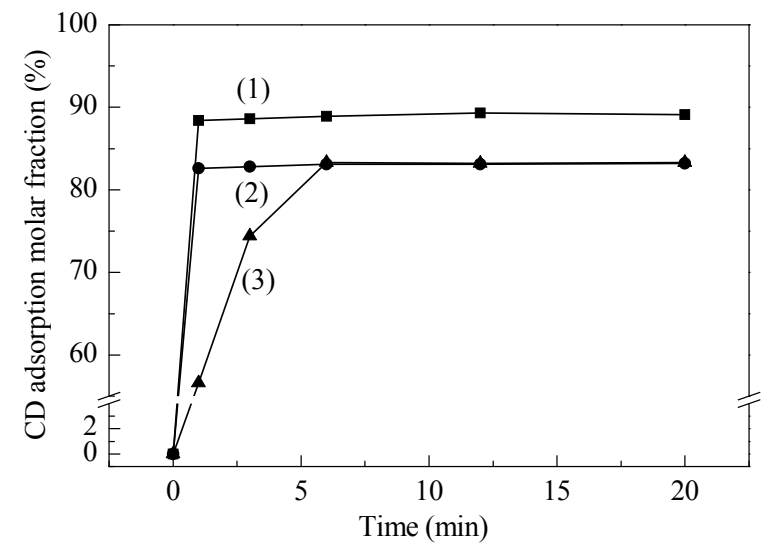

Fig. 3. Adsorption kinetics of $\mathrm{CD}$ versus adsorption time on (1) Pt/CNTs(in), (2) Pt/CNTs(out), and (3) ox-CNTs. 


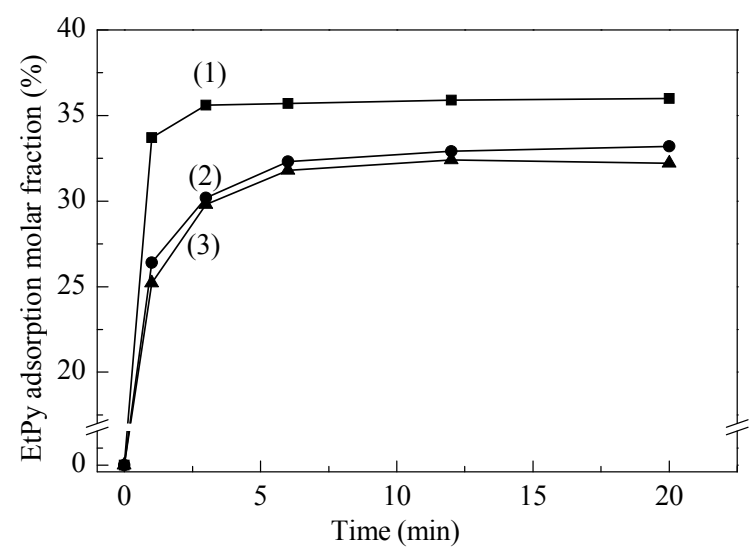

Fig. 4. Adsorption kinetics of EtPy versus adsorption time on (1) Pt/CNTs(in), (2) Pt/CNTs(out), and (3) ox-CNTs.

oxygen containing groups of EtPy. From the adsorption results, it can be concluded that ox-CNTs first enrich the CD and EtPy reactants in the channels and then the more electrophilic $\mathrm{Pt}$ nanoparticles confined in the channels promote the interaction between CD/EtPy and the Pt nanoparticles.

Besides the role of the oxidized Pt species in the adsorption of the chiral modifier, $\mathrm{CD}$, and reactant, the more fundamental issue is what caused the different distribution of the oxidized Pt species between Pt/CNTs(in) and Pt/CNTs(out). Recently it was reported that residual alkali metal ions (such as $\mathrm{Na}^{+}, \mathrm{K}^{+}$) in the catalyst enhanced the catalytic performance of $\mathrm{Pt} / \mathrm{TiO}_{2}$ in formaldehyde oxidation [41] and $\mathrm{Pt} / \mathrm{SiO}_{2}$ in the water-gas shift reaction [42]. One important role of alkali metal ions is to enhance the stability of the Pt species in a highly oxidized state due to the formation of Pt- $(\mathrm{ONa})_{x}$ moieties [41-43]. In the preparation of Pt/CNTs(in) and Pt/CNTs(out), sodium formate was used to reduce the Pt precursor. Even after the samples were fully washed with deionized water, the $\mathrm{Na}^{+}$concentration in Pt/CNTs(in) measured by inductively coupled plasma (ICP) optical emission spectrometry was still as high as $1.7 \mathrm{wt} . \%$, and higher than the 0.6 wt.\% in Pt/CNTs(out). In the absence of Pt, only 0.3 wt.\% $\mathrm{Na}^{+}$exist in both ox-CNTs-in and ox-CNTs-out.

To investigate the influence of the residual $\mathrm{Na}^{+}$on the distribution of the oxidized Pt species, another two reference catalysts were prepared similar to the preparation of Pt/CNTs(in). The corresponding XPS analysis was carried out. One was denoted as Pt/CNTs(in- $\left.\mathrm{H}_{2}\right)$. It was pre-reduced in a hydrogen stream at $90{ }^{\circ} \mathrm{C}$ for $1 \mathrm{~h}$ instead of in sodium formate solution after the introduction of Pt precursor into the channels and the drying procedure. The Pt nanoparticles of Pt/CNTs(in- $\left.\mathrm{H}_{2}\right)$ were well dispersed in the channels of CNTs (Fig. 5(a)). The other reference catalyst was denoted as $\mathrm{Pt} / \mathrm{CNTs}\left(\mathrm{H}_{2}\right)$, which was prepared similarly to $\mathrm{Pt} / \mathrm{CNTs}\left(\mathrm{in}-\mathrm{H}_{2}\right)$, with $\mathrm{Pt}$ nanoparticles randomly dispersed inside and outside the channels of the CNTs (Figure 5(b)). The size of the $\mathrm{Pt}$ nanoparticles in $\mathrm{Pt} / \mathrm{CNTs}\left(\mathrm{in}-\mathrm{H}_{2}\right)$ and $\mathrm{Pt} / \mathrm{CNTs}\left(\mathrm{H}_{2}\right)$ were almost identical to those in Pt/CNTs(in) or Pt/CNTs(out) (Table 3).

Table 4 displays the distribution of the oxidized Pt species in $\mathrm{Pt} / \mathrm{CNTs}(\mathrm{in}), \mathrm{Pt} / \mathrm{CNTs}\left(\mathrm{in}-\mathrm{H}_{2}\right), \mathrm{Pt} / \mathrm{CNTs}\left(\mathrm{H}_{2}\right)$ and Pt/CNTs(out), and their catalytic activity in the asymmetric hydrogenation of

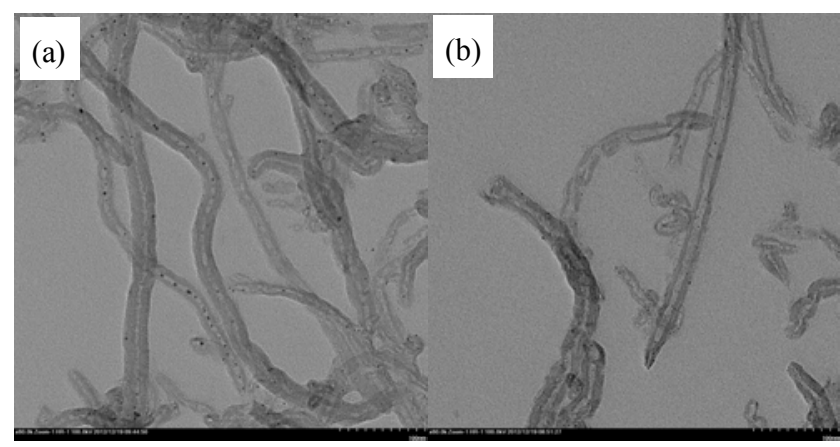

Fig. 5. TEM images of (a)Pt/CNTs(in- $\left.\mathrm{H}_{2}\right)$ and (b) $\mathrm{Pt} / \mathrm{CNTs}\left(\mathrm{H}_{2}\right)$.

EtPy. The residual $\mathrm{Na}^{+}$influenced the distribution of the oxidized Pt species. For Pt/CNTs(in- $\left.\mathrm{H}_{2}\right)$ with no $\mathrm{Na}^{+}$residual, although the oxidized Pt species was 35\% of the Pt species, no highly oxidized Pt species existed after it was reduced in a hydrogen stream at $225{ }^{\circ} \mathrm{C}$ for $2 \mathrm{~h}$ (Method A, Table 4, entry 3). $\mathrm{Pt} / \mathrm{CNTs}\left(\mathrm{in}-\mathrm{H}_{2}\right)$ as the catalyst gave only $72 \%$ enantioselectivity. Due to the absence of residual $\mathrm{Na}^{+}, \mathrm{Pt} / \mathrm{CNTs}\left(\mathrm{H}_{2}\right)$ showed a

\section{Table 3}

Metal dispersion and Pt nanoparticle size of Pt/CNTs determined by CO chemisorption.

\begin{tabular}{|c|c|c|c|}
\hline Catalyst & $\begin{array}{c}\text { Active metal } \\
\text { surface aera } \\
\left(\mathrm{m}^{2} / \mathrm{g}\right)\end{array}$ & $\begin{array}{c}\text { Metal } \\
\text { dispersion } \\
(\%)\end{array}$ & $\begin{array}{c}\text { Average Pt } \\
\text { particles size } \\
(\mathrm{nm})\end{array}$ \\
\hline $\mathrm{Pt} / \mathrm{CNTs}(\mathrm{in})^{\mathrm{A}}$ & 3.8 & 31 & 3.7 \\
\hline $\mathrm{Pt} / \mathrm{CNTs}(\mathrm{in})^{\mathrm{B}}$ & 3.6 & 29 & 3.9 \\
\hline $\mathrm{Pt} / \mathrm{CNTs}(\mathrm{in})^{\mathrm{C}}$ & 3.4 & 28 & 4.1 \\
\hline Pt/CNTs(out) ${ }^{\mathrm{A}}$ & 3.8 & 31 & 3.7 \\
\hline $\mathrm{Pt} / \mathrm{CNTs}$ (out) ${ }^{\mathrm{B}}$ & 3.4 & 28 & 4.1 \\
\hline Pt/CNTs(out)c & 3.4 & 27 & 4.2 \\
\hline $\mathrm{Pt} / \mathrm{CNTs}\left(\mathrm{in}-\mathrm{H}_{2}\right)^{\mathrm{A}}$ & 3.7 & 30 & 3.7 \\
\hline $\mathrm{Pt} / \mathrm{CNTs}\left(\mathrm{H}_{2}\right)^{\mathrm{A}}$ & 3.4 & 28 & 4.1 \\
\hline
\end{tabular}

A-Catalyst treated in $225^{\circ} \mathrm{C} \mathrm{H}_{2}$ stream for $2 \mathrm{~h}$ after the sample was outgassed at $120^{\circ} \mathrm{C}$ for $6 \mathrm{~h}$.

B-Catalyst treated in $300{ }^{\circ} \mathrm{C} \mathrm{H}_{2}$ stream for $2 \mathrm{~h}$ after the sample was outgassed at $120^{\circ} \mathrm{C}$ for $6 \mathrm{~h}$.

C-Catalyst treated in $400{ }^{\circ} \mathrm{C} \mathrm{H}_{2}$ stream for $2 \mathrm{~h}$ after the sample was outgassed at $120^{\circ} \mathrm{C}$ for $6 \mathrm{~h}$.

\section{Table 4}

XPS data and catalytic activity of Pt/CNTs(in), Pt/CNTs(out) and the reference catalysts in the asymmetric hydrogenation of EtPy.

\begin{tabular}{|c|c|c|c|c|c|c|c|c|}
\hline Entry & Catalyst & Method & $\mathrm{Pt}^{0}$ & $\mathrm{Pt}^{2+}$ & $\mathrm{Pt}^{4+}$ & $\begin{array}{c}{\left[\mathrm{Na}^{+}\right]} \\
\text {(wt.\%) }\end{array}$ & $\begin{array}{c}\text { TOF } \\
\left(10^{4} \mathrm{~h}^{-1}\right)\end{array}$ & $\begin{array}{r}\text { ee } \\
\text { (\%) } \\
\end{array}$ \\
\hline 1 & $\mathrm{Pt} / \mathrm{CNTs}(\mathrm{in})$ & A & 63.7 & 22.9 & 13.4 & 1.7 & 9.6 & 95 \\
\hline 2 & $\mathrm{Pt} / \mathrm{CNTs}$ (in) & - & 79.5 & 13.4 & 7.1 & 1.7 & 7.4 & 90 \\
\hline 3 & $\mathrm{Pt} / \mathrm{CNTs}\left(\mathrm{in}-\mathrm{H}_{2}\right)$ & $A$ & 64.6 & 35.4 & 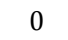 & 0 & 8.1 & 72 \\
\hline 4 & $\mathrm{Pt} / \mathrm{CNTs}\left(\mathrm{in}-\mathrm{H}_{2}\right)$ & B & 80.4 & 19.6 & 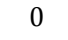 & 0 & 5.9 & 60 \\
\hline 5 & $\mathrm{Pt} / \mathrm{CN}$ & 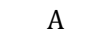 & 7 & 3 & 0 & 0 & 3. & 71 \\
\hline 6 & $\mathrm{Pt} / \mathrm{CN}$ & B & 80.6 & 19.4 & 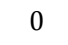 & 0 & 2.1 & 62 \\
\hline 7 & $\mathrm{Pt} / \mathrm{CN}^{\prime}$ & 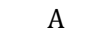 & 67.3 & 32.7 & 8 & 0.6 & 1. & 74 \\
\hline 8 & $\mathrm{Pt} / \mathrm{CNTs}$ (out) & B & 79.6 & 20.4 & 0 & 0.6 & 0.2 & 62 \\
\hline
\end{tabular}

Reaction conditions: $10 \mathrm{mg}$ of Pt/CNTs, $2.0 \mathrm{mg}$ cinchonidine (6.725 umol), $0.2 \mathrm{~mL}$ of substrate, $2 \mathrm{~mL}$ acetic acid (containing $0.96 \mathrm{wt} . \%$ water), $\mathrm{H}_{2}$ pressure of $6.5 \mathrm{MPa}, 20{ }^{\circ} \mathrm{C}$. Reaction time: $3 \mathrm{~min}$ for $\mathrm{Pt} / \mathrm{CNTs}$ (out) and $1 \mathrm{~min}$ for others.

A $-\mathrm{H}_{2}$ reduction at $225^{\circ} \mathrm{C}$ for $2 \mathrm{~h}$ before test.

$\mathrm{B}-\mathrm{H}_{2}$ reduction at $400^{\circ} \mathrm{C}$ for $2 \mathrm{~h}$ before test. 
similar distribution of the oxidized $\mathrm{Pt}$ species as $\mathrm{Pt} / \mathrm{CNTs}\left(\mathrm{in}-\mathrm{H}_{2}\right)$ and gave $71 \%$ enantioselectivity (Table 4, entry 5). By comparing the distribution of the oxidized Pt species of these four catalysts, we concluded that residual $\mathrm{Na}^{+}$in the catalyst played an important role in stabilizing the oxidized $\mathrm{Pt}$ species, especially the highly oxidized Pt species, which are crucial for high enantioselectivity in the asymmetric hydrogenation of EtPy.

The adsorption of CD and EtPy on Pt/CNTs(in- $\left.\mathrm{H}_{2}\right)$ showed that the $\mathrm{CD}$ and EtPy adsorption molar fraction on $\mathrm{Pt} / \mathrm{CNTs}\left(\mathrm{in}-\mathrm{H}_{2}\right.$ ) with no residual $\mathrm{Na}^{+}$was lower than that on Pt/CNTs(in) with more highly oxidized Pt species (Figs. 6 and 7).

The results above showed that the difference in the distribution of the oxidized Pt species between Pt/CNTs(in) and $\mathrm{Pt} / \mathrm{CNTs}$ (out) was dependent on the $\mathrm{Na}^{+}$residual amounts. More highly oxidized Pt species were stabilized when there is $\mathrm{Na}^{+}$in the channels of the CNTs. The highly oxidized Pt species promoted the interaction between CD/EtPy and the Pt nanoparticles, which is crucial for high enantioselectivity in the asymmetric hydrogenation of EtPy. However, the influence of the oxidized Pt species on the activity was not obvious.

\subsection{Hydrogen adsorption activity of the catalysts}

Hydrogen temperature programmed desorption ( $\mathrm{H}_{2}$-TPD) data are displayed in Fig. 8, which showed that no hydrogen desorption was detected below $500{ }^{\circ} \mathrm{C}$ for the pristine CNTs

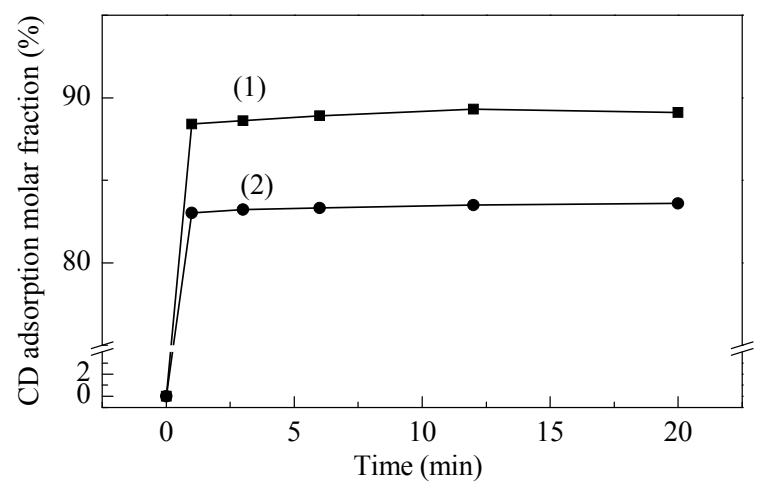

Fig. 6. Adsorption of CD versus adsorption time on (1) Pt/CNTs(in) and (2) Pt/CNTs(in- $\left.\mathrm{H}_{2}\right)$.

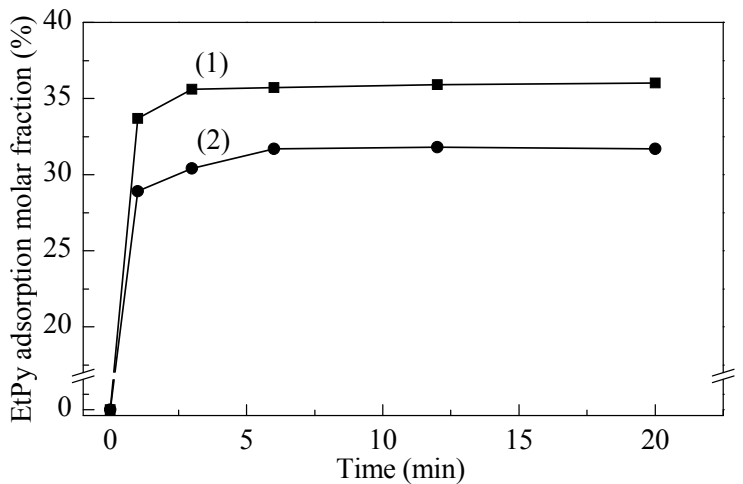

Fig. 7. Adsorption of EtPy versus adsorption time on (1) Pt/CNTs(in) and (2) Pt/CNTs(in- $\left.\mathrm{H}_{2}\right)$.

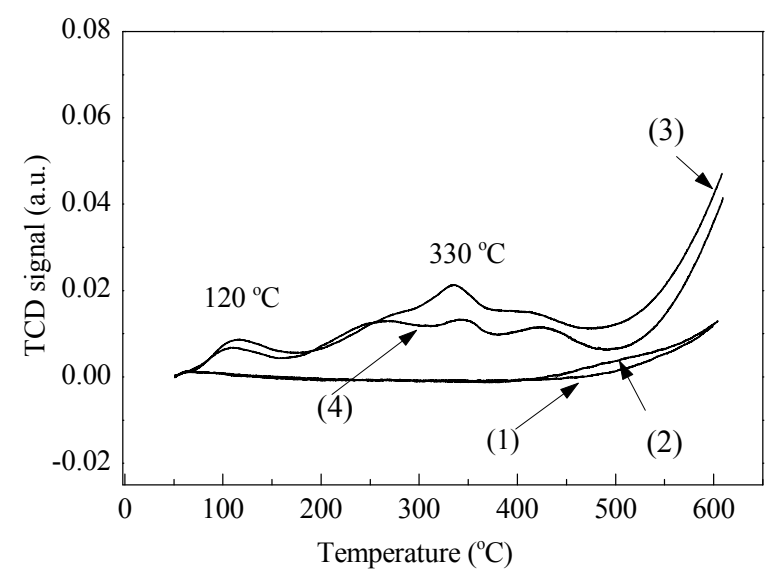

Fig. 8. $\mathrm{H}_{2}$-TPD profiles of (1) pristine CNTs, (2) ox-CNTs, (3) Pt/CNTs (in), and (4) Pt/CNTs(out).

and oxidized CNTs (denoted as ox-CNTs, used as the support). The hydrogen desorption above $600{ }^{\circ} \mathrm{C}$ can be attributed to the decomposition of $\mathrm{CH}^{\bullet}$ in CNTs-pristine and CNTs-oxide [44]. Both Pt/CNTs(in) and Pt/CNTs(out) have a wide desorption peak from 200 to $400{ }^{\circ} \mathrm{C}$ and a small desorption peak at $120^{\circ} \mathrm{C}$. For Pt/CNTs(in), the hydrogen desorption peaks at $120{ }^{\circ} \mathrm{C}$ and $330{ }^{\circ} \mathrm{C}$ were much larger than those of Pt/CNTs(in- $\left.\mathrm{H}_{2}\right)$ and $\mathrm{Pt} / \mathrm{CNTs}$ (out).

The hydrogen desorption peaks in the range of $400{ }^{\circ} \mathrm{C}$ to $600{ }^{\circ} \mathrm{C}$ can be ascribed to the desorption of chemisorbed hydrogen on Pt $[45,46]$. The desorption peaks at $300{ }^{\circ} \mathrm{C}$ and even lower temperatures indicated a weaker interaction between hydrogen and Pt. This weak interaction can be ascribed to weakly bonded hydrogen on Pt that has a higher hydrogenation activity [47]. The $\mathrm{H}_{2}$-TPD result clearly showed that $\mathrm{Pt} / \mathrm{CNTs}$ (in) has more more active hydrogen than $\mathrm{Pt} / \mathrm{CNTs}$ (out) as the amount of hydrogen in the lower temperature region was more for Pt/CNTs(in) than Pt/CNTs(out).

Considering the limited space in the channels, the hydrogen concentration around the Pt nanoparticles confined in the channels was much higher than that around the Pt nanoparticles outside the channels. Recent theoretical simulations also indicated that hydrogen is enriched in the channels of CNTs [48]. Inspired by the $\mathrm{H}_{2}$-TPD results, the asymmetric hydrogenation of EtPy under different hydrogen pressure was conducted to investigate the influence of hydrogen adsorption activity on the catalytic activity of Pt/CNTs(in) and Pt/CNTs(out) (Table 5). With the decrease of hydrogen pressure from 6.5 to $0.1 \mathrm{MPa}$, the TOF of Pt/CNTs(out) decreased significantly from $1.6 \times 10^{4}$ to $140 \mathrm{~h}^{-1}$ (Table 5, entries 4 and 6 ). However, Pt/CNTs(in) could still maintain a high TOF at a hydrogen pressure of $0.1 \mathrm{MPa}\left(\mathrm{Pt} / \mathrm{CNTs}\right.$ (in): $0.6 \times 10^{4} \mathrm{~h}^{-1}$, Table 5 , entry 3). From the reaction conditions in Table 5, it can be proposed that the reaction rate can be expressed by the following kinetic equations:

$$
\begin{gathered}
R_{\text {out }}=k P_{\text {out }^{n}} \\
P_{\text {in }}=K{ }_{\mathrm{P}} P_{\text {out }} \\
R_{\text {in }}=k P_{\text {in }}{ }^{n}=k\left(K_{\mathrm{P}} P_{\text {out }}\right)^{n}
\end{gathered}
$$

$R$ stands for the reaction rate of the asymmetric hydrogenation of EtPy, $k$ stands for the rate constant, $P$ stands for the hy- 
Table 5

Catalytic activity of Pt/CNTs(in) and Pt/CNTs(out) under different $\mathrm{H}_{2}$ pressures in the asymmetric hydrogenation of EtPy.

\begin{tabular}{lcccc}
\hline Entry & Catalyst & $\mathrm{H}_{2}(\mathrm{MPa})$ & $\mathrm{TOF}\left(\mathrm{h}^{-1}\right)$ & ee $(\%)$ \\
\hline 1 & Pt/CNTs(in) & 6.5 & $9.6 \times 10^{4}$ & 95 \\
2 & Pt/CNTs(in) & 1.0 & $1.5 \times 10^{4}$ & 88 \\
3 & Pt/CNTs(in) & 0.1 & $0.6 \times 10^{4}$ & 86 \\
4 & Pt/CNTs(out) & 6.5 & $1.6 \times 10^{4}$ & 74 \\
5 & Pt/CNTs(out) & 1.0 & 210 & 62 \\
6 & Pt/CNTs(out) & 0.1 & 140 & 60 \\
\hline
\end{tabular}

Reaction conditions: $10 \mathrm{mg}$ of Pt/CNTs, $2.0 \mathrm{mg}$ cinchonidine $(6.725$ $\mu \mathrm{mol}), 0.1 \mathrm{~mL}$ of substrate, $2 \mathrm{~mL}$ acetic acid (containing $0.96 \mathrm{wt} . \%$ water), $25{ }^{\circ} \mathrm{C}$. Reaction time: $1 \mathrm{~min}$ for Pt/CNTs(in) and $3 \mathrm{~min}$ for $\mathrm{Pt} / \mathrm{CNTs}$ (out).

drogen pressure and $K_{\mathrm{P}}$ is defined as the enrichment factor of Pt/CNTs(in) under a hydrogen pressure of $P$. From the results in Table 5 (entry 4 and 5), the index $n$ in Eq. (1) was estimated to be 2.3. Therefore, the enrichment factor $\mathrm{K}_{\mathrm{P}}$ under different hydrogen pressures can be calculated. For Pt/CNTs(in), $K_{6.5 \mathrm{MPa}}=2.3 ; K_{1.0 \mathrm{MPa}}=6.3 ; K_{0.1 \mathrm{MPa}}=5.2$. From the kinetic point of view, hydrogen was enriched in the channels, which led to the much higher activity of Pt/CNTs(in) than that of Pt/CNTs(out) at low hydrogen pressure. These results clearly demonstrated that the enrichment of hydrogen in the channels also contributed to the high activity.

\section{Conclusions}

Highly oxidized Pt species can be stabilized inside the channels of CNTs when $\mathrm{Na}^{+}$is present. The more electrophilic Pt species in the highly oxidized state promoted the interaction between the chiral modifier/reactant with the Pt nanoparticles, which is crucial for high enantioselectivity in the asymmetric hydrogenation of EtPy. The enrichment of hydrogen in the channels also contributed to the high activity. These results provide information for understanding why the catalytic performance of Pt located inside the channels of CNTs is much higher than that outside the channels. This work also revealed that the function of the CNTs as a nano-reactor is not only to enrich the molecules inside the channels but also to stabilize the chemical state of Pt in the higher oxidative state.

\section{References}

[1] Zhang Y, Zhang H B, Lin G D, Chen P, Yuan Y Z, Tsai K R. Appl Catal A, 1999, 187: 213

[2] Zhang A M, Dong J L, Xu Q H, Rhee H K, Li X L. Catal Today, 2004, 93-95: 347

[3] Castillejos E, Debouttiere P J, Roiban L, Solhy A, Martinez V, Kihn Y, Ersen O, Philippot K, Chaudret B, Serp P. Angew Chem Int Ed, 2009, 48: 2529

[4] Chen W, Fan Z L, Pan X L, Bao X H. J Am Chem Soc, 2008, 130: 9414

[5] Abbaslou R M M, Tavassoli A, Soltan J, Dalai A K. Appl Catal A, 2009, 367: 47

[6] Pan X L, Fan Z L, Chen W, Ding Y J, Luo H Y, Bao X H. Nat Mater, 2007, 6: 507

[7] Guo S J, Pan X L, Gao H L, Yang Z Q, Zhao J J, Bao X H. Chem Eur J, 2010, 16: 5379

[8] Zhang J, Muller J O, Zheng W Q, Wang D, Su D S, Schlogl R. Nano Lett, 2008, 8: 2738

[9] Zhang H B, Pan X L, Liu J Y, Qian W Z, Wei F, Huang Y Y, Bao X H. ChemSusChem, 2011, 4: 975

[10] Pan X L, Bao X H. Chem Comm, 2008: 6271

[11] Serp P, Castillejos E. ChemCatChem, 2010, 2: 41

[12] Pan X L, Bao X H. Acc Chem Res, 2011, 44: 553

[13] Castillejos E, Serp P. In: Guldi D M, Martin N eds. Carbon Nanotubes and Related Structures. Weinheim WILEY-VCH, 2010. 321

[14] Balázsik K, Szori K, Szollosi G Bartok M. Chem Commun, 2011, 47: 1551

[15] Szollosi G, Makra Z, Kovacs L, Fulop F, Bartok M. Adv Synth Catal, 2013, 355: 1623

[16] Szollosi G, Kovacs L, Makra Z. Catal Sci Technol, 2015, 5: 697

[17] Xing L, Du F, Liang J J, Chen Y S, Zhou Q L. J Mol Catal A, 2007, 276: 191

[18] Szollosi G, Nemeth Z, Hernadi K, Bartok M. Catal Lett, 2009, 132: 370

[19] Chen Z J, Guan Z H, Li M R, Yang Q H, Li C. Angew Chem Int Ed, 2011, 50: 4913

[20] Guan Z H, Lu S M, Chen Z J, Li C. J Catal, 2013, 305: 19

[21] Szollosi G, Hanaoka T, Niwa S, Mizukami F, Bartok M. J Catal, 2005, 231: 480

[22] Szollosi G, Herman B, Felfoldi K, Fulop F, Bartok M. Adv Synth Catal, 2008, 350: 2804

[23] Sugimura T, Uchida T, Watanabe J, Kubota T, Okamoto Y, Misaki T, Okuyama T. J Catal, 2009, 262: 57

[24] Guan Z H, Lu S M, Li C. J Catal, 2014, 311: 1

[25] Wagner C D. In: Muilenberg G E ed. Handbook of X-Ray Photoelectron Spectroscopy. Minnesota Perkin-Elmer Corporation, 1979.

\section{Graphical Abstract}

Chin. J. Catal., 2015, 36: 1535-1542 doi: 10.1016/S1872-2067(15)60831-2

\section{Highly oxidized Pt species stabilized inside carbon nanotubes for asymmetric hydrogenation}

Zaihong Guan, Shengmei Lu, Can Li*

Dalian Institute of Chemical Physics, Chinese Academy of Sciences

$\mathrm{Pt}^{4+}$ species stabilized inside carbon nanotubes facilitated the coordination of the chiral modifier and entrapment of the reactant to give high enantioselectivity in the asymmetric hydrogenation of $\alpha$-ketoester.

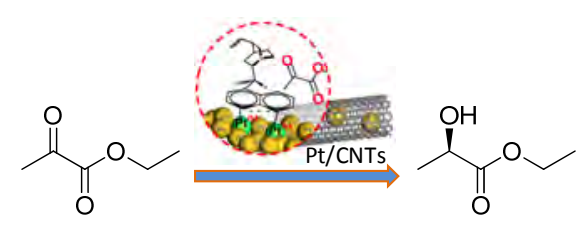<smiles>C=CC1CC2CCN1C2C(O)c1ccnc2ccccc12</smiles>

cinchonidine (CD) 
152

[26] Mallat T, Orglmeister E, Baiker A. Chem Rev, 2007, 107: 4863

[27] Maeda N, Hungerbühler K, Baiker A. J Am Chem Soc, 2011, 133: 19567

[28] Wagner C D. In: Muilenberg G E ed. Handbook of X-Ray Photoelectron Spectroscopy. Minnesota Perkin-Elmer Corporation, 1979. 42

[29] Smirnov M Yu, Vovk E I, Kalinkin A V, Pashis A V, Bukhtiyarov V I. Kinet Catal, 2012, 53: 117

[30] Liu X H, Guo Y, Xu W J, Wang Y Q, Gong X Q, Guo Y L, Guo Y, Lu G Z. Kinet Catal, 2011, 52: 817

[31] Kalinkin A V, Smirnov M Yu, Nizovskii A I, Bukhtiyarov V I. J Electron Spectrosc Relat Phenom, 2010, 177: 15

[32] Corro G, Fierro J L G, Odilon V C. Catal Commun, 2003, 4: 371

[33] Orito Y, Imai S, Niwa S, Hung N G. J Synth Org Chem, 1979, 37: 173

[34] Orito Y, Imai S, Niwa S. J Chem Soc Jpn, 1979: 1118

[35] Blaser H U, Studer M. Acc Chem Res, 2007, 40: 1348

[36] Bartok M. Curr Org Chem, 2006, 10: 1533

[37] Murzin D, Maki-Arvela P, Toukoniitty E, Salmi T. Catal Rev Sci Eng,
2005, 47: 175

[38] Zaera F. Acc Chem Res, 2009, 42: 1152

[39] Vargas A, Santarossa G, Baiker A. J Phys Chem C, 2011, 115: 1969

[40] Bonalumi N, Burgi T, Baiker A. J Am Chem Soc, 2003, 125: 13342

[41] Zhang C B, Liu F D, Zhai Y P, Ariga H, Yi N, Liu Y C, Asakura K, Flytzani-Stephanopoulos M, He H. Angew Chem Int Ed, 2012, 51: 9628

[42] Zhai Y P, Pierre D, Si R, Deng W L, Ferrin P, Nilekar A U, Peng G W, Herron J A, Bell D C, Saltsburg H, Mavrikakis M, Flytzani-Stephanopoulos M. Science, 2010, 329: 1633

[43] Zhu X L, Shen M, Lobban L L, Mallinson R G.J Catal, 2011, 278: 123

[44] Zhang H B, Lin G D, Zhou Z H, Dong X, Chen T. Carbon, 2002, 40: 2429

[45] Li X S, Chen Y X, Li W Z. React Kinet Catal Lett, 1996, 58: 377

[46] Miller J T, Meyers B L, Modica F S, Lane G S, Vaarkamp M, Koningsbergery D C. J Catal, 1993, 143: 395

[47] Khan N A, Zellner M B, Chen J G. Surf Sci, 2004, 556: 87

[48] Guan J, Pan X L, Liu X, Bao X H.J Phys Chem C, 2009, 113: 21687

\title{
稳定于碳纳米管的Pt高价态物种在不对称氢化反应中的作用
}

\author{
管再鸿, 卢胜梅, 李 灿 ${ }^{*}$ \\ 中国科学院大连化学物理研究所催化基础国家重点实验室, 辽宁大连 116023
}

\begin{abstract}
摘要: 碳纳米管的独特性质, 特别是其一维有序的管腔结构所形成的限域环境在催化反应中的应用引起了广泛的兴趣. 已有将常 规的液相氢化反应和气相反应限域于碳纳米管内的研究报道, 并且大多数的研究结果显示限域于碳纳米管内的反应活性和/或选 择性有明显提高, 但多数研究没有对此给出清晰的解释. 金鸡纳碱修饰的Pt催化剂催化的 $\alpha$-酮酸酯不对称氢化体系被认为是多相 不对称催化领域发展的里程碑. 早期的研究是简单的将碳纳米管作为 Pt催化剂的载体用于 $\alpha$-酮酸酯不对称氢化反应, 取得了中等 的活性和对映体选择性. 我们研究组发展了一种催化剂制备方法, 可选择性的将Pt纳米粒子限域于碳纳米管管腔内或担载在碳纳 米管管外, 并将所制备的碳纳米管Pt催化剂应用于 $\alpha$-酩酸酯多相不对称催化反应中, 发现封装于管腔内的管内型Pt纳米粒子的催 化性能显著高于负载在管腔外壁的管外型Pt纳米粒子的催化性能. 然而, 对于管内型Pt催化剂催化性能增强的原因并不清楚. CO 化学吸附和高分辨投射电镜(HRTEM)的表征结果表明管腔内外的Pt纳米粒子的大小和形貌没有明显区别. 本论文在上述研究基 础上, 采用X射线光电子能谱(XPS), 氢气程序升温脱附 $\left(\mathrm{H}_{2}-\mathrm{TPD}\right)$, 紫外可见光谱(UV-Vis)等表征手段研究了Pt纳米粒子担载于碳 纳米管内和管外形成的催化剂在 $\alpha-$ 酮酸酯的不对称氢化反应中催化性能差异的原因.

XPS测试结果表明, 管内型和管外型Pt催化剂的载体的碳物种分布没有显出差异, 但催化活性中心Pt纳米粒子的Pt物种组成 不同. 经 $225^{\circ} \mathrm{C} \mathrm{H}_{2}$ 还原后管外型Pt催化剂不存在高氧化态的Pt物种, 而管内型 $\mathrm{Pt}$ 催化剂在 $400{ }^{\circ} \mathrm{C}_{2}$ 还原仍然具有 $7 \%$ 的高氧化态 $\mathrm{Pt}$ 物种. 相应的催化反应结果表明, 具有这种稳定的高氧化态Pt物种有利于获得高对映体选择性. 参比催化剂商业化的 Pt/AC和 $\mathrm{Pt} / \mathrm{Al}_{2} \mathrm{O}_{3}$ 的XPS测试结果也表明, 对映体选择性高的 $\mathrm{Pt} / \mathrm{Al}_{2} \mathrm{O}_{3}$ 催化剂具有较高含量的高氧化态 $\mathrm{Pt}$ 物种. 同时我们发现高氧化态 $\mathrm{Pt}$ 物 种有利于催化剂对手性修饰剂和反应底物的吸附. 虽然文献中一般认为 $\mathrm{Pt}^{0}$ 是该反应的活性中心, 但我们认为这些高氧化态的 $\mathrm{Pt}$ 物种有利于纳米粒子和手性修饰剂之间的相互作用, 从而提高反应的对映选择性. 我们进一步研究了表明高氧化态的P物种能存 在于碳纳米管管腔内的原因. 发现在催化剂制备过程中所使用的还原剂甲酸钠中残留的钠离子能稳定碳纳米管管腔内高氧化态 $\mathrm{Pt}$ 物种. 我们采用 $\mathrm{H}_{2}$ 直接还原制备了不含钠离子的参比管内型 $\mathrm{Pt}$ 催化剂. 该参比催化剂的对映体选择性与管外型 $\mathrm{Pt}$ 催化剂相当, 明显低于管内型Pt催化剂. 同时该参比催化剂对手性修饰剂和底物的吸附能力弱于管内型Pt催化剂. 以上结果清晰的表明了碳 纳米管内由钠离子稳定的高氧化态Pt物种在 $\alpha$-酮酸酯多相不对称催化反应中的重要作用.

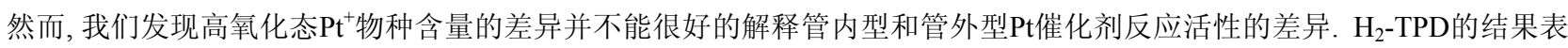
明相比于管外型Pt纳米粒子催化剂, 管内型Pt纳米粒子具有更高的活化氢分子的能力, 相应的催化反应结果表明, 管外型Pt催化剂 的反应活性随 $\mathrm{H}_{2}$ 压力的降低而显著降低, 而管内型Pt催化剂在 $0.1 \mathrm{MPa}_{2}$ 条件下仍然具有较高活性. 简单的动力学模拟结果表明, 在 $0.1 \mathrm{MPa}_{2}$ 条件下, 碳纳米管管腔能显著富集 $\mathrm{H}_{2}$.
\end{abstract}

关键词: 碳纳米管; $\alpha$-酩酸酯; 不对称氢化; 铂纳米粒子; 氧化态

收稿日期: 2015-01-20. 接受日期: 2015-03-03. 出版日期: 2015-09-20.

*通讯联系人. 电话: (0411)84379070; 传真: (0411)84694447; 电子信箱: canli@dicp.ac.cn

基金来源：国家自然科学基金(20921092,21227801).

本文的英文电子版由Elsevier出版社在ScienceDirect上出版(http://www.sciencedirect.com/science/journal/18722067). 